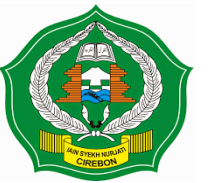

(Journal Islamic Education of Management)

https://www.syekhnurjati.ac.id/jurnal/index.php/jiem

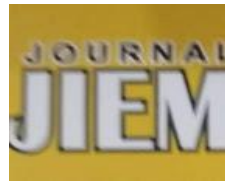

\title{
MANAJEMEN KELAS DALAM MENINGKATKAN PRESTASI BELAJAR SISWA DI SEKOLAH DASAR ISLAM TERPADU
}

\author{
Muhammad Kusman \\ Sekolah Tinggi Agama Islam Miftahulhuda Subang \\ e-mail: M.kusman62@gmail.com
}

\begin{abstract}
Abstrak
Tujuan penelitian ini ialah untuk mengungkap secara mendalam mengenai manajemen kelas dalam meningkatkan prestasi belajar siswa di sekolah dasar Islam terpadu Alamy Subang. Penelitian ini adalah penelitian kualitatif lapangan dengan menggunakan pendekatan kualitatif. Subyek penelitian ialah para guru, wali kelas, siswa. Untuk mendapatkan data, maka penulis menggunakan instrumen observasi mendalam, wawancara mendalam, dan studi dokumentasi. Analisis data meliputi pengumpulan data, reduksi data, penyajian data dan penarikan kesimpulan atau verifikasi. Penarikan kesimpulan dari hasil analisis data digunakan metode induktif dan deduktif. Hasil penelitian menunjukkan bahwa implementasi manajemen kelas untuk meningkatkan prestasi belajar peserta didik di SDIT Alamy Subang dapat dilakukan dengan baik, sarana dan prasarana yang tersedia sudah cukup memadai, sehingga guru cukup dapat berinovasi dalam pembelajaran dan metode digunakan bisa bervariasi sehingga berpengaruh pada sisi akademik yang sudah cukup baik. Faktor pendukung, yakni sarana prasarana yang cukup memadai, guru yang berkompeten sejalan bidangnya masing-masing, tempat yang cukup strategis, aman, dan lingkungan sekitar sekolah yang bersih. Faktor penghambat, yakni keragaman karakteristik peserta didik, guru pengampu dan wali kelas yang berbeda persepsi dalam manajemen kelas.
\end{abstract}

Kata Kunci: Pengelolaan Kelas, Prestasi belajar, Guru

\section{Abstract}

The purpose of this study was to reveal deeply about classroom management in improving student achievement in the integrated Islamic elementary school Alamy Subang. This research was a qualitative field research. The research subjects were teachers, homeroom teachers and students. To obtain data, the authors used in-depth observation, in-depth interviews, and documentation studies. Data analysis included data collection, data reduction, data presentation and drawing conclusions or verification. Drawing conclusions from the results of data analysis used inductive and deductive methods. The results showed that the implementation of classroom management to improve student achievement can be done well. The facilities and infrastructure were adequate. It made the teacher can innovate in learning. The teaching methods were varied, so that it influenced good academic achievement. Supporting factors, namely adequate infrastructure, competent teachers, quite strategic, safe, and clean environment. Inhibiting factors were the diversity of students' characteristics, different perceptions of class management of teachers and homeroom teachers.

Keywords: Classroom Management, Learning Achievement, Teachers 


\section{A. Pendahuluan}

Sekolah Dasar adalah jenjang pendidikan formal di tingkat dasar yang dipakai sebagai tempat belajar yang diharapkan bisa membangun jiwa dan karakter siswa. Pendidikan adalah proses berkelanjutan. Proses pendidikan menerapkan eksistensi siswa yang mempunyai kemampuan sebagai makhluk sosial, dan makhluk yang senantiasa dinamis (Mikarsa, 2009:15). Oleh sebab itu, pendidikan mesti mempunyai tujuan pembelajaran yang pada dasarnya ialah pengembangan kemampuan siswa yang berguna bagi kehidupan pribadinya ataupun bagi warga negara maupun warga masyarakat lainnya.

Guna meningkatkan kualitas pendidikan dibutuhkan bagi peningkatan pendidikan, yakni berhubungan erat dengan peningkatan mutu pembelajaran secara operasional yang diselenggarakan di dalam kelas. Diantaranya dengan implementasi pengelolaan kelas dalam proses pembelajaran.

Manajemen kelas adalah suatu upaya yang acapkali dijadikan perhatian penting oleh para guru baru, calon guru, dan bahkan guru yang sudah berpengalaman sekalipun. Manajemen kelas adalah serangkaian perilaku guru yang dengan sengaja dilakukan untuk memelihara dan menciptakan keadaan kelas yang memungkinkan siswa mencapai tujuan belajarnya secara efisien, memungkinkan siswa belajar dengan optimal, bisa memanfaatkan bakatnya, kemampuannya, dan energinya pada tugas-tugas individual (Chandra, 2015:13-15; Lopes, 2017:467-490).

Manajemen kelas yang dilaksanakan oleh guru dalam proses pembelajaran dapat mengkondisikan terjadinya interaksi antara guru dan peserta didik sebab ia akan terdorong untuk belajar sebagai upaya untuk merealisasikan hasil belajar yang maksimal sebab didukung oleh lingkungan belajar yang kondusif. Guru sebagai motor penggerak dalam proses belajar mengajar mesti dapat memaksimalkan berbagai hal yang berkaitan dengan aktivitas belajar mengajar. Guru adalah pemegang peranan penting dalam proses belajar (Jagtap, 2016:3903-3905). Aktivitas belajar mengajar adalah suatu proses yang memuat sejumlah perbuatan guru dan peserta didik atau dasar hubungan timbal balik yang berjalan dalam kondisi edukatif untuk mencapai tujuan. Guru sebagai pengelola aktivitas belajar mengajar dan sebagai kreator, inisiator, dan fasilitator dan mesti dapat menciptakan kondisi belajar-mengajar 
yang efektif dan dapat mengembangkan berbagai hal yang berhubungan dengan aktivitas belajar mengajar tersebut (Nezamedini, 2013: 281-299; Kafu dan Simwelo, 2015).

\section{Berdasarkan penjelasan Nana}

Sudjana (2010:22) bahwa hasil belajar ialah kemampuan yang dimiliki peserta didik sesudah menerima pengalaman belajarnya. Peserta didik dinilai berhasil dalam belajarnya, jika bisa mengembangkan kemampuan pengetahuannya dan mendapatkan pengembangan sikap serta memahami yang sudah dipelajarinya. Dari hal-hal tersebut, jelaslah bahwa alasan dipergunakannya manajemen kelas oleh guru dalam menciptakan keadaan belajar yang kondusif dan menyenangkan yang sangat besar pengaruhnya pada kegiatan belajar peserta didik, sehingga bisa meningkatnya kegiatan belajar peserta didik dengan tujuan untuk mendapatkan hasil belajar yang maksimal.

SDIT Alamy Subang adalah sekolah swasta yang dilengkapi dengan sarana prasarana cukup memadai. Sejumlah prestasi cukup ditorehkan sekolah ini baik akademis maupun non akademis. Hal inilah yang nampaknya di antara daya tarik masyarakat untuk menyekolahkan anak-anaknya di sekolah dasar ini tersebut. Berpijak pada penjelasan di atas, penulis tertarik untuk meneliti secara mendalam mengenai bagaimana manajemen kelas dalam meningkatkan prestasi belajar peserta didik yang dilakukan di SDIT Alamy Subang.

\section{B. Metode Penelitian}

Penelitian adalah penelitian kualitatif lapangan studi kasus. Lokasi penelitian di SDIT Alamy Subang. Sedangkan subjek penelitian ini ialah beberapa guru atau wali kelas, dan para siswa di SDIT Alamy Subang yang beralamat di Jalan Ki Hajar Dewantara Nomor 1b, Dangdeur, Kecamatan Subang, Kabupaten Subang, Jawa Barat. Penelitian dilaksanakan dari tanggal 1 Agustus - 2 Oktober 2019). Untuk mendapatkan data, maka penulis menggunakan instrumen observasi mendalam, wawancara mendalam, dan studi dokumentasi. Data yang sudah didapatkan dianalisis dengan menggunakan metode deskriptif kualitatif yang meliputi pengumpulan data, reduksi data, penyajian data dan penarikan kesimpulan atau verifikasi (Kurniawan, 2018:241). Penarikan kesimpulan dari hasil analisis data digunakan metode induktif dan deduktif. 


\section{Hasil Penelitian dan Pembahasan}

SDIT Alamy Subang sudah melaksanakan manajemen kelas guna membangun suasana pembelajaran yang maksimal guru membangun lingkungan belajar yang menyenangkan dan nyaman, diantaranya melalui pemajangan hasil karya-karya peserta didik sehingga perhatian mereka dapat terfokus kepada pelajaran. Hal tersebut sejalan dengan teknik penciptaan suasana belajar yang maksikmal seperti diutarakan oleh White, et al, (2009), yakni kemampuan guru dalam melakukan inisiatif penciptaan kondisi pembelajaran agar berada dalam suasana yang kondusif sehingga perhatian peserta didik terfokus pada bahan ajar. Guru memperlihatkan respon yang baik melalui tanggapan positif jika keadaan kelas yang gaduh, ada yang belum memahami materi, dan lain-lain. Hal itu sejalan dengan sikap tanggap yang diarahkan agar eksistensi guru di dalam pembelajaran di kelas betul-betul dirasakan oleh peserta didik. Dalam memusatkan perhatian pada materi pelajaran, bahwa guru mengelompokkan siswa ke dalam kelompok kecil dan berkreativitas dengan metode menarik. Hal ini sejalan dengan teknik memusatkan perhatian sebagaimana dijelaskan oleh Wahyu Winarto, bahwa situasi belajar bisa dipertahankan jika selama proses pembelajaran berlangsung guru dapat mempertahankan konsentrasi peserta didik, yakni dengan teknik memusatkan perhatian (wawancara 6-7 Agustus 2019).

Guru memberikan tujuan dan petunjuk yang jelas. Hal ini belum dilaksanakan secara optimal sebab tidak seluruh guru memberi tujuan dan petunjuk yang jelas. Hal ini tidak sejalan dengan teknik memberikan tujuan dan petunjuk yang jelas sebagaimana diutarakan oleh Ade Nurhikmah, bahwa peserta didik dapat belajar dengan perhatian maksimal jika memahami tujuan yang mesti dicapai dan mengerti apa yang mesti dilaksanakan (wawancara 29 Agustus 2019).

Guru menegur dan menguatkan melalui teguran, sanksi berupa ucapan istigfar, tugas atau hafalan bagi siswa yang gaduh dan tidak disiplin di kelas. Hal tersebut sejalan dengan teknik pemberian teguran dan penguatan sebagaimana dijelaskan oleh Dewi guru SDIT Alamy Subang, bahwa teguran dibutuhkan demi perubahan perilaku ke arah yang lebih baik (wawancara 29 Agustus 2019).

Dalam perencanaan pembelajaran dan pengorganisasian sejumlah sumber belajar dan tujuan pembelajaran di 
SDIT Alamy Subang pada tahun ini memberlakukan kurikulum nasional dan kurikulum sekolah Islam terpadu terutama. Dalam rangka mencapai tujuan pembelajaran yang optimal dengan membuat kelas kondusif mungkin tanpa adanya ganggguan dari luar untuk merealisasikan lingkungan belajar mengajar yang nyaman. Hal tersebut sejalan dengan merencanakan pembelajaran dan tujuan pembelajaran yang dijelaskan oleh Wahyu Winarto, yakni memperkirakan kebutuhan dan tuntutan, menetapkan tujuan, menulis silabus aktivitas pembelajaran, menyusun sejumlah tema yang hendak dipelajari, mengalokasikan waktu serta memanfaatkan sumber-sumber yang dibutuhkan dan penciptaan dengan sengaja suatu lingkungan pembelajaran yang nyaman dalam merealisasikan tujuan pembejalaran yang sudah ditetapkan. Dalam memimpin, memotivasi, membimbing, dan menstimulasi peserta didik dan mengawasi berbagai hal, apakah telah berjalan sebagaimana seharusnya atau belum dalam pencapaian tujuan, guru memiliki peran dalam mendorong peserta didik dalam pembelajaran, menstimulasinya dengan memberikan pembelajaran sebaik dan semenyenangkan mungkin serta membantunya yang mendapatkan kesulitan dalam memahami materi pelajaran. Guru memiliki tugas untuk memeriksa dan mengawasi pembelajaran di dalam kelas apakah telah sejalan dengan tujuan pembelajaran atau belum. Disini guru memantau hasil belajar peserta didik, baik yang berupa tugas ataupun hasil pekerjaan di kelas. Hal tersebut sejalan teori memimpin, yang menyangkut motivasi dan stimulasi peserta didik dan mengawasi apakah telah sebagaimana mestinya atau belum dalam pembelajaran untuk mencapai tujuan, yakni untuk meningkatkan motivasi peserta didik agar mereka menerima dan melatih tanggungjawab untuk mandiri.

Sedangkan manajemen kelas yang terkait dengan fisik di SDIT Alamy Subang telah cukup baik meskipun masih ada sejumlah hal yang belum sejalan seperti penataan lemari disebabkab tidak seluruh kelas ada almarinya, pengaturan sejumlah media pembelajaran seperti alat peraga yang belum tersusun rapi. Adapun teori yang dijelaskan oleh Cheryan, et al (2014:412), hal yang mesti diperhatikan dalam pengelolaan fisik, yakni ruangan tempat berjalannya proses pembelajaran, pengaturan alat-alat peraga, ventilasi dan tata cahaya, pengaturan penyimpanan barang-barang, 
pengaturan formasi duduk, penataan keindahan dan kebersihan kelas, dan lain-lain (Toftuma, et al, 2015: 494503).

Adapun faktor pendukung manajemen kelas di sekolah ini ialah lingkungan yang bersih, guru yang berkompeten sesuai bidangnya, seleksi masuk yang cukup mendetail, sarana prasarana yang mendukung, lokasi yang aman dan strategis. Hal ini sejalan dengan hasil riset Saifi, et al (2018) bahwa penciptaan situasi belajar yang maksimal bisa mempengaruhi kualitas prestasi belajar, sosialisasi wali kelas terhadap masyarakat, mengenai SDIT Alamy Subang. Sedangkan faktor penghambat ialah keragaman karakteristik peserta didik, guru atau wali kelas yang berbeda persepsi mengenai manajemen kelas .

Sedangkan pemecahan masalah terhadap faktor-faktor penghambat di atas, di antaranya berhubungan dengan karakteristik peserta didik yang berbeda dengan membuat peraturan tertentu yang disetujui bersama bagi kelancaran pembelajaran, yang disusun dalam wujud tata tertib kelas sebagai bentuk kontrak belajar dengan peserta didik untuk membangun kedisiplinan peserta didik, persamaan pandangan melalui rapat (diskusi) yang terkait dengan perkembangan siswa untuk menciptakan pembelajaran yang efektif dan efisien.

\section{Kesimpulan dan Saran}

Implementasi manajemen kelas untuk meningkatkan prestasi belajar peserta didik di SDIT Alamy Subang dapat dilakukan dengan baik, sarana dan prasarana yang tersedia sudah cukup memadai, sehingga guru cukup dapat berinovasi dalam pembelajaran dan metode digunakan bisa bervariasi sehinga berpengaruh pada sisi akademik yang sudah cukup baik. Faktor pendukung, yakni sarana prasarana yang cukup memadai, guru yang berkompeten sejalan bidangnya masing-masing, tempat yang cukup strategis, aman, lingkungan sekitar sekolah yang bersih, dan sosialisasi wali kelas terhadap masyarakat. Faktor penghambat, yakni keragaman karakteristik peserta didik, guru pengampu dan wali kelas yang berbeda persepsi dalam manajemen kelas. Adapun pemecahan dalam mengatasi hambatan yang dihadapi, yakni berhubungan dengan karakteristik peserta didik yang berbeda dengan menyusun aturan tertentu yang disetujui bersama dalam wujud tata tertib kelas sebagai kontrak belajar, persamaan pandangan yang mengenai perkembangan siswa. 


\section{Daftar Pustaka}

Chandra, Ritu. 2015. "Classroom Management for Effective Teaching". International Journal of Education and Psychological Research (IJEPR), 4 (4), 13-15.

Cheryan, Sapna, Sianna A. Ziegler, Victoria C. Plaut, and Andrew N. Meltzoff, 2014. Designing Classrooms to Maximize Student Achievement. Policy Insights from the Behavioral and Brain Sciences, 1(1) 4-12.

Kafu, Patrick A., dan Genvieve N. Simwelo. 2015. "Reforms and Innovations in Teacher Education: Facilitator of Access, Quality and Equity as Emerging Issues in Education in Kenya". British Journal of Education, 3 (2), 45-60.

Kurniawan, Asep. 2018. Metodologi Penelitian Pendidikan. Bandung: Remaja Rosdakarya.

Jagtap, Prakash. 2016. "Theachers Role as Facilitator in Learning". an International Peer Reviewed \& Referred Scholarly Research Journal for Humanity Science \& English Language, 3 (17), 3903-3905.

Lopes, João, Elisabete Silva, Célia Oliveira, Daniel Sass, Nancy Martin. 2017. “Teacher's Classroom Management Behavior and Students' Classroom Misbehavior: A Study with 5th through 9th-Grade Students". Electronic Journal of Research in Educational Psychology, 15 (3), 467-490.

Mikarsa, Hera Lestari. 2009. Pendidikan Anak di SD. Jakarta: Universitas Terbuka.

Nezamedini, Maryam Sadat. 2013. "A Study of the Relationship between English Teachers' Approaches to Teaching and Students' Incivilities". International Journal of English Language Education, 1 (1), 281-299.

Saifi, Imran Latif, Mohammad Iftikhar, Lubna Salamat, Muzaffar Hussain.
2018. "Impact opf Classroom Management on Students Achievement at University Level". Asian Journal of Social Sciences \& Humanities, 2(2),13-27.

Sudjana, Nana. 2010. Dasar-dasar Proses Belajar. Bandung: Sinar Baru.

Toftuma, Jørn, Birthe U. Kjeldsena, Pawel Wargockia, Henriette R. Menåa, Eva M.N. Hansena, Geo Clausen. 2015. "Association between Classroom Ventilation Mode and Learning Outcome in Danish Schools". Building and Environment, 92, 494503.

White, Mary Johnston. 2009. "The Teachergarten: Creating an Environment Conducive to Meaningful Teacher Growth”. Early Childhood Education Journal, $37: 171$ 